\title{
The Drop Effect at the Doctoral Supervision Sea Surface: Observing the Waves with the Supervisor Lens
}

\author{
Isabel Ribau \\ Department Applied Social Science, NOVA School of Science and Technology, NOVA Lisbon University, Portugal
}

Received February 20, 2020; Revised March 19, 2020; Accepted March 28, 2020

Copyright $\odot 2020$ by authors, all rights reserved. Authors agree that this article remains permanently open access under the terms of the Creative Commons Attribution License 4.0 International License

\begin{abstract}
Doctoral education can be seen as a conclusion of postgraduate Education and the highest achieving degree, remaining in the higher education area domain, or moves further towards the research area as the first stage of research careers (doctoral training). In this sense, it's the bridge between two areas, the education system and the research system. It is the particular characteristic that makes doctoral education so important to a developer and innovative society. In Portugal only a few years ago, the doctoral education started being a research object. To underpin the knowledge about doctoral education at Universidade Nova de Lisboa, research aimed to capture the supervisor conceptions and perceptions was implemented. This paper aims to describe what was found and what was, in the context of a Portuguese university (that doesn't demand as rule supervisors have a pedagogical or even a supervision course (formation)), unpredicted and unexpected. The first effect of this research was to start supervisors' self-reflection about their practices and aims of supervision. The second was the emergence of difficulties assumed by the supervisors during the supervision process, not only related to the institution, but also to the students' motivation and engagement in the research process and the perception of the necessity of development skills to manage conflicts.
\end{abstract}

Keywords Doctoral Supervision, Doctoral Supervisors, Supervisors' Needs, Supervisors' Perceptions

\section{Introduction}

The third cycle is the higher education cycle that allows the acquisition of the doctoral degree ( $\mathrm{PhD}$ degree). It comprises a wide variety of doctorates, with different models and structures, ranging from fully or partially structured and schooled doctorates to unstructured doctorates. These models have several implications not only in supervision process, and in the resources applied in the development of the doctorate but also in the doctoral student enrolment status (part-time/full-time students, employed in host institutions or researchers at an early stage of their career/young professionals). They are influenced by an institution's policy and the possibility of links between the institutions and industry or social organizations. In this context, questions related to the aims of pursuing a $\mathrm{PhD}$ arise: the $\mathrm{PhD}$ training is the deepening and the discovery of knowledge through original research and the first state of an academic career, or on the other hand, it is a time to develop skills to meet the expectations of the labour market which may be one of the options at the end of the doctorate. Regarding this, Repečkaité highlighted that "doctoral education and training are at the core of the so-called European paradox, where Europe's population enjoys good quality and accessible education, but educational attainment does not translate into industrial and commercial innovation" (Repečkaité, 2016: 256). In this sense, doctoral education is the connection between the higher education system and the research system.

In the doctoral process, two phases can be distinguished: the school phase and the research phase. In the research phase, supervision of doctoral research has four dimensions: "the advisory role, the quality control role, the supporting relationship nurtured by the supervisor and the guidance of the student by the supervisor (Mouton, 2001, p. 17, cited by Beer \& Mason, 2009). In this sense doctoral supervision is a teaching and learning process, on the doctoral education core, that takes place between doctoral student and supervisor, which is based on a relationship with boundaries that must be defined between them, being constantly negotiated and reconstructed, underlying power issues (Petersen, 2007). This process focus is the formation/construction of the $\mathrm{PhD}$ student's identity "becoming an academic" - which is subjective and operationalized by its integration with the academic environment, by interaction with other researchers (for instance, in meetings, in the academic environment), 
participating in conferences and congresses by writing articles, but also through reading and research. But it can be only the process through which the researcher is (re)constructed and their skills and competence are developed. Maxwell and Smyth (2010 and 2011), when studying doctoral supervision, refer to the unequal power relationship between doctoral student and supervisor that changes over time; at the end of the doctorate, the student should have more knowledge in the investigated area than the supervisor. They propose that supervision should focus on the student, on the knowledge and the research project (process and product of supervision).

The doctoral supervisor is someone from the academy with great knowledge in the area of a research project who will guide and advise the doctoral student through the research process during the doctoral period. The supervisor is, therefore, an educator and a leader. Usually, his "knowledge is indorsed in everyday practice" (Orlikowski, 2002), is important for his supervisory practice, his experience as a $\mathrm{PhD}$ student and the relationship he established with his advisor (Wright, Murray \& Geale, 2007). The range and depth of concepts and knowledge that the supervisor has will dictate how he supervises, the type of research that appears at the end of the supervision process, and the research work the student will perform (Lee, 2007).

During the supervision process, the supervisor should develop core skills in research and provide inputs that enable student development (Ismail, Abiddin, Hassan \& Ro'is, 2014), being the academic training very important to achieve these goals (Shibayama, 2018).

Franke and Arvidsson looked at the supervision process and concluded that supervisory practices, can be distinguished by how they are structured: they can be researched practice-oriented and research relation-oriented. In the first one, supervisory practices develop around common research practices and the sharing of research objects, such as similar research approaches. In the latter, the research problem and research objects are not related to the supervisor's research project (Franke \& Arvidsson, 2011). Supervisors who have research-oriented practices promote traditional research, being mediators of practices, sometimes experiencing double roles. On the other hand, supervisors whose practices are guided by the relationship, are seen by doctoral students as dialogue partners and mediators of knowledge and experience and perceived as mentors. These supervisors not only promote research-oriented supervisory practices, but also interpersonal relationships.

Hyatt and William, in 2011, drew up a list of competencies, cited by Jones (Jones, 2013: 92): the teaching role competencies, advising role competencies, research role competencies, service role competencies, colleagueship role competencies. Developing these skills in areas as diverse as teaching and counselling, peer work and research skills are critical to provide supervisors with effective and quality supervision. Mention should also be made to the quality descriptors for supervision (ORPHEUS, 2011 and 2012), in which the supervisor's responsibilities include: counselling on the project, monitoring and process documentation, observation of ethics and scientific conduct, support in the development of the doctoral career, support in the insertion of the doctoral student in international scientific networks and the academic community. Also, Gardner (2007) specified that PhD supervisors should be accessible to students, give positive and regular feedback on doctoral students' pathway, show that they care about doctoral students, should treat doctoral students as colleagues or peers, and support doctoral students in their research.

To Pearson and Brew (2002), the supervisor provides the doctoral student, who is the centre of the supervisory process, with a high quality investigative and learning environment which will "(...) facilitate the student becoming an independent professional researcher and scholar in their field, capable of adapting to various research areas, whether university or industry-based (...)" (2002: 139). In this sense, supervisory practices are all the learning experiences of the doctoral journey, which aims to equip him with research skills, procedural or methodological skills, epistemological skills, communication skills, attitudes and ethical skills, axiological skills among others and which should make him grow as a person and develop as a researcher. In this context, supervisory practices are an important part of the doctoral curriculum, which is no longer just the scholarly part of the doctorate and his thesis (constructed knowledge) but includes all the activities that the doctoral student performs during the doctoral research period.

The centre of doctoral education is the tasks and practices executed by the student, Fig. 1 .

The activities and the academic training will depend on the supervisor and the doctoral student: the supervisor must take into account the student's profile, adopt strategies for personal and professional development/ growth (which relates to curriculum differentiation and adaptation) and monitor the progress of the doctoral student and evaluate the extent that is taking effect and achieving the goals set by the doctor (supervisor) and the institution. Sometimes the supervisor will be the engine of the doctoral process, giving the student motivation and encouragement, allowing the doctoral student to be the leader of his research. These different roles must be internalized by the supervisor for the doctoral student to build himself as a researcher. At a second level comes the institution that gives the physical support, the resources and the regulations, the research team where the student was integrated, but also the thesis monitoring committee and the other doctoral students. Each of this group has its mission, being the monitoring committee, to monitor and evaluate the course of the project and report to the host institution - Scientific Council. The research team will 
(implicitly) have the role of supporting and encouraging the student, integrating him into the institution and "showing" how to work in a team (both cooperative and collaborative work), doctoral colleagues (belonging or not at the same group), facilitate socialization and integration into academia, but also provide motivational support. In the last layer, is the development of the doctoral project, which, using the synergies created by the two previous levels, will be materialized in the products of the research process (doctoral research project, the researcher, papers, knowledge, thesis, professional career). Assessment and monitoring of the doctoral research project should be carried out throughout the process, by both the student and the supervisor. Assessment is understood here as "the systematic collection of information on which to make a value judgment that facilitates decision making" (Peralta, 2002). A formative assessment should be done during the doctoral research to correct the biases that may arise. The regulation that both monitoring and evaluation allow, promote not only the investigative process normal course, but also, boost the student and supervisor reflection to understand if the investigation is going in the right direction. Monitoring and evaluation of supervision can be performed at different levels, Fig. 2.

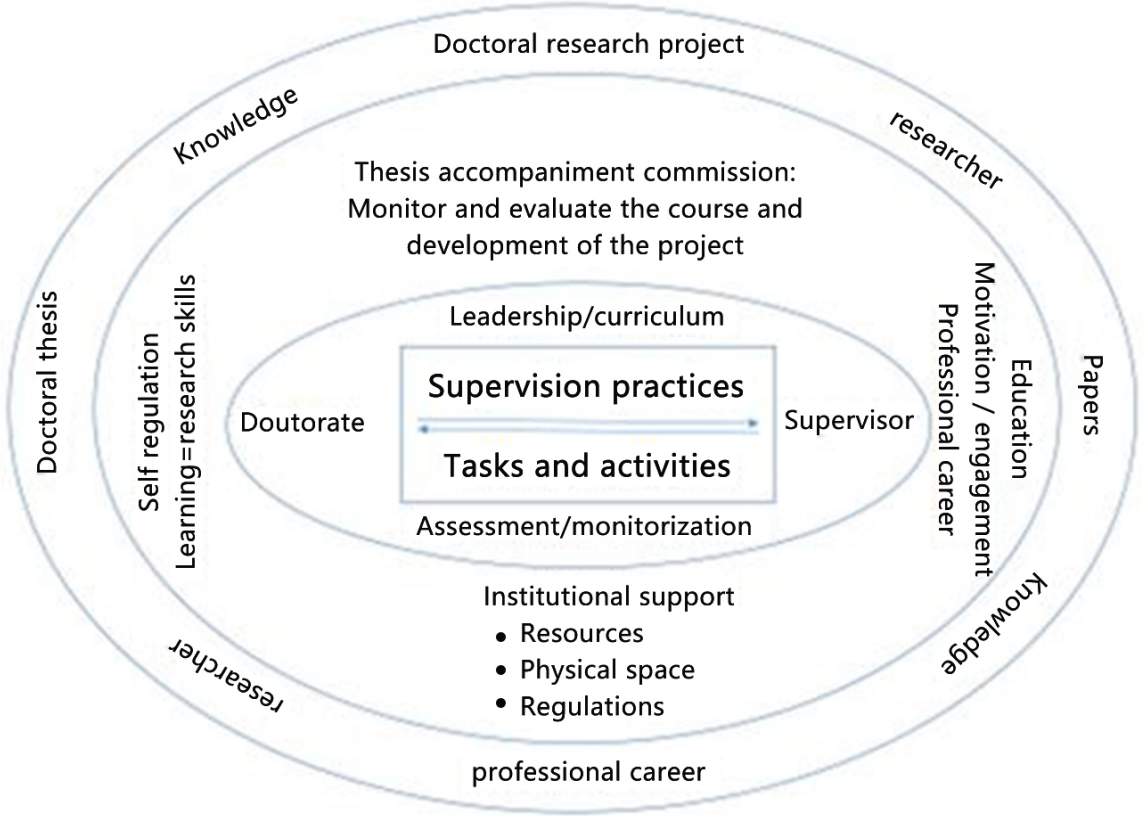

Figure 1. PhD globalizing model, which presents the different levels of interaction from supervisory practices to goals

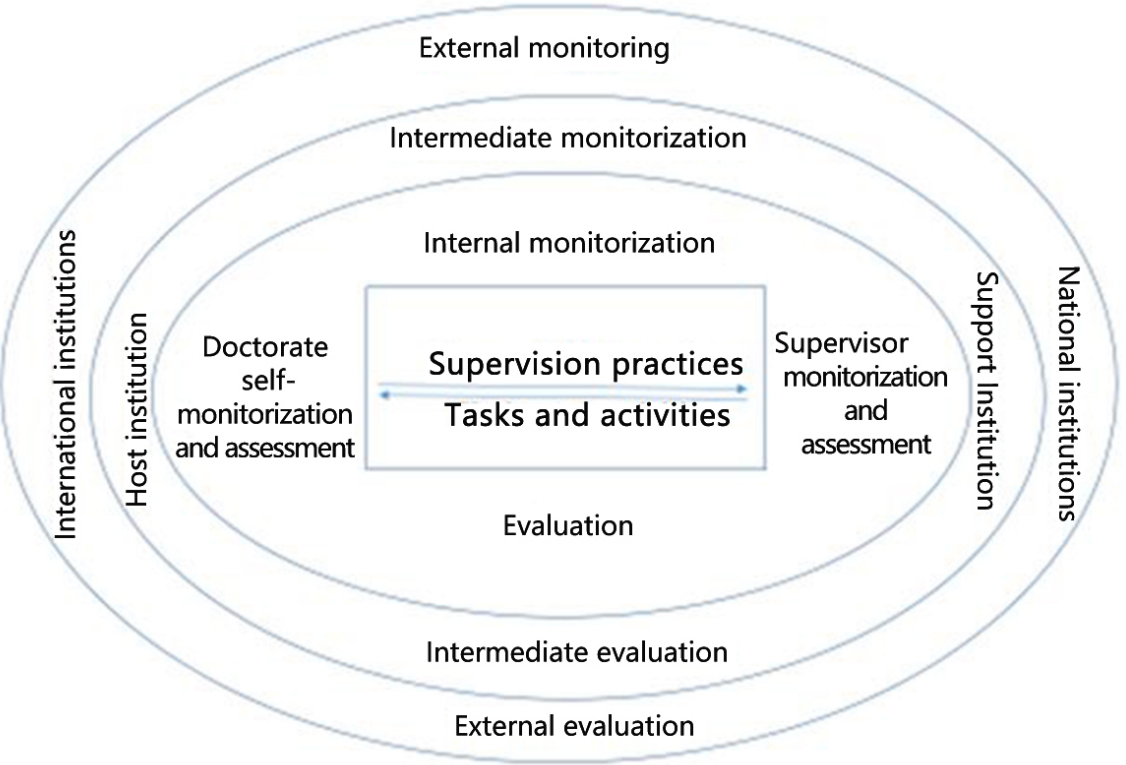

Figure 2. The monitoring and evaluation environment in a supervision process 
At the first level, monitoring is performed by the student at an operational level: he plans, executes, manages, evaluates his performance, how he will achieve his goals, and reformulates or continues his student project plan. The supervisor should also monitor the activities, attend the $\mathrm{PhD}$ student on his journey, advising and analysing the results obtained by the doctoral student and encourage it to proceed. In this follow-up, the supervisor must present research tools (which should be specific to the subject area, but also transversal all subject areas) to the student but also motivate and encourage it to pursue his research. Supervisor monitor and evaluation of the research developed will allow the student to achieve doctoral goals. The supervisor may use as a tool, the information given by the doctoral student (oral and written feedback, reports, etc.), direct observation and written records of the supervisor himself. The next level of monitoring and evaluation of supervision should be carried out by the institution (thesis follow-up committees or by the scientific and pedagogical councils of the host institution) who report on the doctoral student's path (outcomes achieved, activities proposed by the supervisor and the activities carried out by the doctoral student). It is important to highlight this intermediate monitorization and evaluation of supervision process is also performed in the defence of the thesis by the thesis jury. At a more external level, monitoring and evaluation will be carried out by institutions outside the host institution, which may be publishers, international agencies or groups of institutions that look within the institution and evaluate its performance number of doctorates completed, retention rates, completion rates, the paper published, supervision quality of, among others), using institution reports or other public reports. The various levels of monitoring and evaluation complement each other and all promote quality supervision.

During the last two decades, the Portuguese Higher Education System has suffered a reform, starting with the implementation of the Bologna process (1999). Although these have occurred, leading to changes in the legislation and a new design in the structure of higher education courses (these maintain a gap related to the absence of doctoral supervisor duties/rights, competencies and responsibilities or practices), until the last decade, doctoral education didn't capture the researcher's in mind. There are two main reasons for that; the first one is that Portugal undergraduate Educational System passes through deepening change during the last twenty years, with profound curriculum changes. The second one is related to the fact that study doctoral education implies analyses the doctoral supervision process, completion rate, socialization processes, supervision practices, quality, doctorate design, careers and employability, but it can focus on the relationship/interaction between a doctorate and their supervisor, and be still a "private place" for almost all supervisors.
This paper aims to present the perceptions of the $\mathrm{PhD}$ supervisors of a Portuguese University, being the drop in the surface of the third cycle. The waves that rise and spread were not captured in this study, but a research project goal was already achieved - it promotes supervisors and students' reflection on doctoral education and their practices.

\section{Methods}

To identify the supervision practices, monitorization and evaluation, a survey was constructed and delivered, via institutional e-mail, to all nine schools that belong to Universidade Nova de Lisboa (Faculdade de Ciências e Tecnologia (FCT); Faculdade de Ciências Sociais e Humanas (FCSH); A NOVA School of Business and Economics (NSBE); NOVA Medical School / Faculdade de Ciências Médicas (NMS/FCM); Faculdade de Direito (FD); Instituto de Higiene e Medicina Tropical (IHMT); NOVA Information Management School (NIMS); Instituto de Tecnologia Química e Biológica António Xavier (ITQB); Escola Nacional de Saúde Publica (ENSP)), and at that point they were sent to the $\mathrm{PhD}$ supervisors. Only $112 \mathrm{PhD}$ supervisors answered the survey. A preliminary study had already been conducted in the same University regarding doctoral supervision, and is published elsewhere (Ribau \& Alves, 2018, Ribau, 2018). The present survey is based on that one. The supervisor survey focuses on: students' profile, supervisor experience in supervision, research project supervision (autonomy, management, planning, monitorization and evaluation), supervision practices, $\mathrm{PhD}$ aims from the supervisor point of view and the socialization process. To answer the survey close questions of doctoral supervisors a Likert scale was used. Supervisors had to agree, partially agreed, partially disagree or disagree with positive and negative statements. In the survey, supervisors had an inventory of supervisory practices and optional open questions. The scale's internal reliability, Cronbach's alpha was 0.960 .

\section{Findings and Discussion}

When a drop of water flows into the water surface, it causes a wave that spreads on the surface and moves the water particle's from the equilibrium position but doesn't change the essence of the water (a wave only carries energy (information) but not particles). This was the effect caused by this research work (the drop) in the doctoral supervision in UNL (water). It focuses on the doctoral supervision and put it in the middle of an emerging movement to improve doctoral education in this university.

This research is a case study of doctoral education at a Portuguese University. The aim of this research was not to 
change, but first to identify the perceptions of supervisors related to their one doctoral supervision practices, feelings and difficulties, second to put doctoral education as an important issue that should be analysed. And third was starting a movement to change and improve doctoral education.

\subsection{Doctoral Supervisor: Characteristics and Difficulties}

The supervisor sample that answered is not homogenous: in some schools, many supervisors answered the questions and in others, they were few, as shown in Table 1. So it was not possible to perceive if there were differences between schools regarding the conceptions of doctoral education.

Table 1. Percentage of Supervisors that answered the survey per UNL School

\begin{tabular}{|l|l|}
\hline $\begin{array}{l}\text { NOVA Lisbon University } \\
\text { Schools }\end{array}$ & $\begin{array}{l}\text { Percentage of Respondent } \\
\text { Supervisors }\end{array}$ \\
\hline FCT & 73.2 \\
\hline FCSH & $\sim 0$ \\
\hline Nova SBE & 4.5 \\
\hline NMS/FCM & - \\
\hline FD & 3.6 \\
\hline IHMT & 2.7 \\
\hline Nova IMS & 1.8 \\
\hline ITQB & 7.2 \\
\hline ENSP & 6.2 \\
\hline Total & 100 \\
\hline
\end{tabular}

Regarding how much time they had their PhD degree, half of the respondent supervisor population refer that they had completed the $\mathrm{PhD}$ degree more than 16 years, but only $30.4 \%$ of these supervisors indicate that they do doctoral supervision, as shown in Table 2.
Table 2. Supervisors percentage, taking into account the date of completion of the doctoral degree and how long they perform the doctoral supervision

\begin{tabular}{|l|c|c|}
\hline \multirow{2}{*}{ Time (Years) } & \multicolumn{2}{|c|}{ Supervisors' percentage (\%) } \\
\cline { 2 - 3 } & PhD conclusion & PhD student supervision \\
\hline 1 to 5 & 5.4 & 24.1 \\
\hline 6 to 10 & 24.1 & 27.6 \\
\hline 11 to 15 & 17.9 & 17.9 \\
\hline $\begin{array}{l}\text { More than } 16 \\
\text { years }\end{array}$ & 52.6 & 30.4 \\
\hline Total & $\mathbf{1 0 0}$ & $\mathbf{1 0 0}$ \\
\hline
\end{tabular}

According to Mosher and Purpel (1972), a supervisor should have the sensitivity to understand the problems and their causes, the ability to analyse, dissect and conceptualize the problems and to hierarchize the root causes, but also the ability to establish effective communication. During supervision, the supervisor should promote the doctoral student a self-training to develop the ability to identify, deepen, mobilizes and integrate the knowledge underlying the research exercise. In this context, the role of the supervisor during the doctoral investigation was analysed as shown in Table 3.

From the collected data, it can be seen that there is no agreement on the perception that supervisors have regarding their main function. It is found that $53.6 \%$ of supervisors partially agree that their main role is to show "methodological tools" to the doctoral student, with $25.9 \%$ agreeing with this statement. A majority of supervisors $(62.5 \%)$ agree with the statement "For the completion of doctoral degree it is important for the supervisor to know how to manage conflict" and 33\% partially agree. $71.4 \%$ of supervisors consider that to guide the student in his doctoral research project the supervisor needs to know the student's project in detail". A vast number of supervisors $(79.5 \%)$ agree and partially agree $(17.0 \%)$ with the assertion "Giving timely feedback is essential in supervision".

Table 3. Degree of supervisors' agreement the supervisor rule.

\begin{tabular}{|c|c|c|c|c|c|c|}
\hline \multirow{2}{*}{ Statement } & \multicolumn{4}{|c|}{ Percentage of respondents by degree of agreement } & \multirow{2}{*}{ Average } & \multirow{2}{*}{$\begin{array}{l}\text { Standard } \\
\text { deviation }\end{array}$} \\
\hline & Agree & Partially agree & Partially Disagree & Disagree & & \\
\hline $\begin{array}{l}\text { The main function of the supervisor is to } \\
\text { show the "methodological tools" that the } \\
\text { student can use, in the development of their } \\
\text { doctoral project. }\end{array}$ & 25.9 & 53.6 & 16.1 & 3.6 & 3.00 & 0.41 \\
\hline $\begin{array}{l}\text { For the completion of the } \mathrm{PhD} \text { degree, the } \\
\text { supervisor must know how to manage } \\
\text { conflict. }\end{array}$ & 62.5 & 33.0 & 2.7 & 1.8 & 3.56 & 1.16 \\
\hline $\begin{array}{l}\text { To guide the student in his doctoral research } \\
\text { project, the supervisor doesn't need to know } \\
\text { the student project in detail. }\end{array}$ & 2.7 & 6.3 & 19.6 & 71.4 & 1.40 & 0.27 \\
\hline Supervisors should be patient. & 66.1 & 27.7 & 3.6 & 0.0 & 3.47 & 1.28 \\
\hline \multirow[t]{2}{*}{$\begin{array}{l}\text { Giving feedback timely is essential in good } \\
\text { supervision. }\end{array}$} & 79.5 & 17.0 & 0.9 & 0.9 & 3.69 & 1.89 \\
\hline & & & & Average & 3.03 & 1.15 \\
\hline
\end{tabular}




\subsection{The Supervisor and Intrinsic Factors That Influence Doctoral Supervision from the Supervisor Point of View}

To identify the purposes, that in supervisors mind, lead a student to start a doctorate, supervisors answer the following open question "What is the main goal of doing a doctorate, besides producing knowledge?" The data collected allows to identify the following main goals, for these supervisors: the research training and the research competence development (reported by $38.5 \%$ of the supervisors), participation in a research team /specialization (mentioned by $28.7 \%$ supervisors), the development of autonomy, resilience and critical spirit (referred by $13.9 \%$ ) and career progression in academy or personal enhancement (assigned by 13.8\%). These results from a conception of a $\mathrm{PhD}$ that emerges in the view of the $\mathrm{PhD}$ journey considering its nature (product, process and context) and a value (utility and importance). Leep, Remmik, Karm and Leijen (2013:401) refer that in their research, the supervisors consider that "a doctoral study aims to prepare future researchers and acquire academic writing skills as quickly as possible". They conceive doctoral studies "as an intermediate process in the course of becoming a researcher." In the present research, the doctoral research is seen as a trainee and specialization in a research area.

In the survey, another open question was proposed regarding the acceptance of doing the $\mathrm{PhD}$ supervision: "What reasons lead a supervisor to guide $\mathrm{PhD}$ students?" The reasons invoked by supervisor, that lead them to carry out doctoral supervision are, the research aid given by $\mathrm{PhD}$ students $(19.1 \%)$, knowledge production $(14.5 \%)$, the necessity for supervisor academic career progression $(12.8 \%)$, personal interest in the research theme $(10.9 \%)$, the professional duty of the supervisor $(10.0 \%)$, knowledge transmission $(9.1 \%)$, creation of research teams $(4.5 \%)$, teaching $(4.5 \%)$, personal accomplishment $(4.5 \%)$, the development of research topics that supervision provides (3.6\%), and paper publication (2.7\%). Shibayama (2018) in a recent paper focus on the academic training and the two dilemmas that are linked with it, "The first dilemma is linked to an intertemporal tradeoff in the effect of autonomous training. (...) The second dilemma is concerned with the allocation of recognition reward between students and supervisors." (Shibayama, 2018: 36). In our results, it is possible to perceive that the majority of the supervisors see the $\mathrm{PhD}$ students as followers and not as future leaders or future independent researcher, as the main reason, to do supervision is personal and is related to the supervisor needs (to have aid in the research, knowledge production to writing papers, personal career). Only a few supervisors have, as the main goal of doing doctoral supervision, developed research skills, like autonomy, critical thinking or creativity, in the $\mathrm{PhD}$ students.
Some authors have identified important factors that may interfere with an academic's decision to choose to accept be a doctoral supervisor: internal factors such as motivation and experience preparation as a supervisor and external factors such as having sources of funding and resources, having work (employment), being able to train/exercise scientific research (Vilkinas, 2008; Askew, Dixon, McCormic, Callaghan, Wang \& Shulruf, 2016; Boehe, 2016; Duke \& Denicolo, 2017). All of these investigations have enabled the identification of possible ways to improve internal and external factors, such as the academy giving more value to supervision, universities allowing supervisors to have time to conduct their own research, assigning a limited number of students to doctorate to each supervisor, encouraging co-orientations and the realization by the supervisors of preparation courses for the supervision of doctoral projects. Some researchers pointed out that the preparation of supervisors to exercise the role of supervisors is important to guide the student through the research process inherent to the $\mathrm{PhD}$ (Abdullah \& Evans, 2012). It should be noted that in most research works, the authors assume that supervisors are competent but emphasize the importance of having a model for their professional development. (Styles \& Radloff, 2001; Gartfield, 2005, Vilkinas \& Cartan 2006; Maxwell \& Smyth, 2011).

Of note is a supervisor's testimony when he states that "Much of the investigators' experimental work is performed by $\mathrm{PhD}$ and postdoctoral students. This is the only way to achieve international productivity rates. Co-supervised students ensure collaborative research." This reality is also referred by Pearson, Evans, and Macauley (2012) but also by Johnston, Sampson, Comer and Brog (2016) and when they emphasise that doctors candidates contribute significantly to the academic life, research outputs and reputation of universities. It is also interesting to perceive that doctoral students are seen, in this research study by the supervisors, as students and not as researchers in early year careers, and this may be because they aren't integrated into an academic career but usually, they have scholarships or grants.

\subsection{The Supervision of the Research Development}

The development of the doctoral research project from the supervisor's point of view was analysed taking into account the phases considered relevant to it: the planning, organization, implementation and management of the research project monitoring, evaluation and student autonomy. Doctoral research should be the centre of the process that is being developed through the planning, execution and management of tasks, which are monitored and evaluated by the doctoral student and the supervisor and will promote the development of the autonomy of the doctoral student.

The knowledge of the tasks that $\mathrm{PhD}$ student must 
perform during the doctorate, and its operational framework, is important for the doctoral student to plan his work not only in terms of research (What to do? When to do?) but also of the work that must be delivered (When? How? and What?), the meetings to attend (What meetings? When?), What type of monitoring will be proposed (What type? When does it occur? Who does it?), what evaluation will there be (what type? When does it occur? Who does it?), which will allow the student to understand not only the goals of their work, but also, what is expected to him.

In this context, the following statement was proposed: "The formalization by the supervisor of the guidelines (tasks to be performed by the student) is fundamental for the completion of the doctorate": $31.3 \%$ of supervisors agree with this statement, $45.5 \%$ partially agree, however, $19.6 \%$ partially disagree with it.

Regarding the statement "Doctoral students must strictly comply with the work plan outlined by me", $28.6 \%$ partially agree with it and $3.6 \%$ agree. The supervisors allow students to change the work plan during the development of the research, which implicitly allows us to infer that supervisors value the autonomy of doctoral students. It is not only necessary to produce a task framework to support the research project, but it is also crucial the time management during doctoral research.

Concerning the doctoral research development, during the doctoral research process, some statements were presented, Table 4.

There is an agreement regarding the research plan. For supervisors, it should be done by the student in collaboration with the supervisor, not been only the supervisor's responsibility. In this context the research project leadership during the $\mathrm{PhD}$ research process is shared by the supervisor and doctoral students.

Research writing is essential to $\mathrm{PhD}$ students not only "to develop their thinking, their knowledge and the identity as researchers (Paré, 2017; Starke-Meyerring, 2011)" (Sala-Bubaré, Peltonen, Pyhältö \& Castelló, 2018: 328) but also to allow them to be part of the research community. But "it involves complex cognitive and social processes of knowledge construction (Bereiter \& Scardamalia, 1987), identity development (Kamler \& Thomson, 2006; Maher, et.al, 2000) and interaction with" the research community (Sala-Bubaré, Peltonen, Pyhältö \& Castelló, 2018: 328). Sala-Bubaré and collaborates (2018) highlight that " Supervisors and doctoral schools need to be aware of difficulties involved in writing at the PhD level for all doctorate candidates (...) and support them in developing transformative research writing perceptions" (Sala-Bubaré, Peltonen, Pyhältö \& Castelló,
2018: 328). In our data the research writing specially the thesis, it is not considered the $\mathrm{PhD}$ hardest task, by supervisors. A majority of supervisors encourage students to write resumes regarding the work done. It should be emphasised that in some UNL schools, it is necessary to publish a paper, in a peer-review publication, before doing the VIVA voice (thesis defence) (Ribau \& Alves, 2017), and that is an outcome of the PhD.

Almost all supervisors (90.2\%) agree that regular contact (by e-mail, Skype, in-person) with doctoral students, is the key to monitoring and guiding student research work. Regular meetings in person with students have an agreement of $76.8 \%$ supervisors. $60.7 \%$ of supervisors agree with joint monitorization ( $\mathrm{PhD}$ student -supervisor) of the development of the doctoral project. $56.3 \%$ of supervisors agree with the statement "Supervisor's failure to monitor student work may lead to non-completion of the doctorate" and that $31.3 \%$ partially agree with this statement.

This data is relevant because indirectly it shows the importance that self-monitoring and supervisor monitoring of the research project represent for the achievement of the doctorate. The lowest percentage of supervisors (39.4\%) who encourage students to write about the work done to promote student self-monitorization and self-reflection on the development of their research project is also noteworthy.

The development of investigative autonomy is very important for supervisors: $86.6 \%$ agreed with the statement "Developing student investigative autonomy is a priority." They also consider that their role is not passive and may interfere/intervene in the process. This conclusion is based on whether $33.9 \%$ of supervisors disagree or $40.2 \%$ partially disagree with the following statement: "A supervisor follows the doctoral research process but does not interfere."

Regarding the assessment of the development of the doctoral research, $19.6 \%$ of the supervisors agree with the statement of "For the supervisor to evaluate the work developed, the student must deliver each semester, a written paper or a portfolio to the supervisor", $37.5 \%$ partially agree, $37.5 \%$ partially disagree and $26.8 \%$ disagree with it. So the questions arise: How supervisors evaluate the students' work development and the accomplished milestones of the research plan? Which are the instruments used and how and when they are used?

The Nature of the doctoral process was analysed, not deepened, but only to perceive the feelings regarding it, as shown inTable 5. 
Table 4. Distribution of items by project development steps

\begin{tabular}{|c|c|c|c|c|c|c|c|}
\hline \multirow{2}{*}{$\begin{array}{l}\text { Doctoral } \\
\text { research } \\
\text { development }\end{array}$} & \multirow{2}{*}{ Statement } & \multicolumn{4}{|c|}{$\begin{array}{c}\text { Percentage of respondents by degree of } \\
\text { agreement }\end{array}$} & \multirow{2}{*}{ Average } & \multirow{2}{*}{$\begin{array}{l}\text { Standard } \\
\text { deviation }\end{array}$} \\
\hline & & Agree & $\begin{array}{c}\text { Partially } \\
\text { agree }\end{array}$ & $\begin{array}{l}\text { Partially } \\
\text { Disagree }\end{array}$ & Disagree & & \\
\hline \multirow[t]{2}{*}{ Planning } & $\begin{array}{l}\text { The planning of the activities to be } \\
\text { carried out under the PhD should be } \\
\text { done jointly with the student. }\end{array}$ & 78.6 & 17.0 & 2.7 & 0.9 & 3.71 & 1.49 \\
\hline & $\begin{array}{l}\text { The planning of the research work is } \\
\text { the responsibility of the supervisor. }\end{array}$ & 6.3 & 53.6 & 26.8 & 11.6 & 2.51 & 0.68 \\
\hline \multirow{2}{*}{$\begin{array}{l}\text { Execution/ } \\
\text { organization }\end{array}$} & $\begin{array}{l}\text { Writing the thesis is the hardest thing } \\
\text { in a doctorate. }\end{array}$ & 5.4 & 30.4 & 39.3 & 25.0 & 2.16 & 0.36 \\
\hline & $\begin{array}{l}\text { Supervisory rules are clarified when } \\
\text { the acceptance of guidance and } \\
\text { co-orientation is formalized. }\end{array}$ & 35.7 & 33.9 & 14.3 & 14.3 & 2.88 & 0.61 \\
\hline \multirow{2}{*}{ Management } & $\begin{array}{l}\text { The most difficult thing about a } \\
\text { doctorate is the correct time } \\
\text { management. }\end{array}$ & 10.7 & 58.9 & 24.1 & 5.4 & 2.73 & 0.75 \\
\hline & $\begin{array}{l}\text { I have a lot of work and little time to do } \\
\text { the supervision. }\end{array}$ & 9.8 & 28.6 & 26.8 & 34.8 & 2.13 & 0.23 \\
\hline \multirow{5}{*}{$\begin{array}{l}\text { The research } \\
\text { project } \\
\text { Monitoring }\end{array}$} & $\begin{array}{l}\text { Failure to monitor student work may } \\
\text { lead to non-completion of the } \\
\text { doctorate. }\end{array}$ & 56.3 & 31.3 & 10.7 & 1.8 & 3.42 & 1.01 \\
\hline & $\begin{array}{l}\text { To guide the work developed by the } \\
\text { student, regular contact is important } \\
\text { (through face-to-face conversations, } \\
\text { email exchanges, meetings via } \\
\text { Skype....) }\end{array}$ & 90.2 & 8.9 & 0.0 & 0.9 & 3.88 & 1.76 \\
\hline & $\begin{array}{l}\text { During orientation I hold regular } \\
\text { meetings with } \mathrm{PhD} \text { students. }\end{array}$ & 76.8 & 20.5 & 0.9 & 0.0 & 3.71 & 1.46 \\
\hline & $\begin{array}{l}\text { To know the work developed by the } \\
\text { student, it is necessary that the } \\
\text { supervisor check, together with the } \\
\text { student, the research development } \\
\text { confronting the initial plan with the } \\
\text { work. }\end{array}$ & 60.7 & 31.3 & 5.4 & 0.9 & 3.48 & 1.12 \\
\hline & $\begin{array}{l}\text { As a supervisor, I encourage the } \\
\text { writing of resumes about the work } \\
\text { done, so that the student can monitor } \\
\text { and reflect on the development of their } \\
\text { research project. }\end{array}$ & 39.3 & 33.0 & 17.0 & 8.0 & 2.98 & 0.67 \\
\hline Assessment & $\begin{array}{l}\text { For the supervisor to evaluate the work } \\
\text { developed, the student must submit } \\
\text { each semester a written paper } \\
\text { (report/monograph/ paper/summary, } \\
\text { etc.) or a portfolio to him. }\end{array}$ & 19.6 & 37.5 & 26.8 & 15.2 & 2.60 & 0.41 \\
\hline \multirow{3}{*}{ Autonomy } & $\begin{array}{l}\text { The development of student } \\
\text { investigative autonomy is a priority. }\end{array}$ & 86.6 & 12.5 & 0.9 & 0.0 & 3.86 & 1.68 \\
\hline & $\begin{array}{l}\text { A supervisor follows the doctoral } \\
\text { research process but does not interfere } \\
\text { with it. }\end{array}$ & 4.5 & 21.4 & 40.2 & 33.9 & 1.96 & 0.28 \\
\hline & & & & & Average & 2.40 & 0.91 \\
\hline
\end{tabular}


Table 5. Analysis of items related to the Nature of academic degree

\begin{tabular}{|c|c|c|c|c|c|c|c|}
\hline \multirow{2}{*}{$\begin{array}{l}\text { PhD Degree nature } \\
\text { from the supervisor } \\
\text { point of view }\end{array}$} & \multirow{2}{*}{ Statement } & \multicolumn{4}{|c|}{$\begin{array}{c}\text { Percentage of respondents by degree of } \\
\text { agreement }\end{array}$} & \multirow{2}{*}{ Average } & \multirow{2}{*}{$\begin{array}{l}\text { Standard } \\
\text { deviation }\end{array}$} \\
\hline & & Agree & $\begin{array}{l}\text { Partially } \\
\text { agree }\end{array}$ & $\begin{array}{l}\text { Partially } \\
\text { Disagree }\end{array}$ & Disagree & & \\
\hline \multirow{4}{*}{ Project authorship } & $\begin{array}{l}\text { The research project of a doctoral } \\
\text { student should clearly articulate } \\
\text { with the research interests of the } \\
\text { supervisor. }\end{array}$ & 41.1 & 42.9 & 11.6 & 4.5 & 3.21 & 0.78 \\
\hline & $\begin{array}{l}\text { The authorship of the dissertation } \\
\text { / thesis is of the student. }\end{array}$ & 52.7 & 29.5 & 12.5 & 5.4 & 3.29 & 0.93 \\
\hline & $\begin{array}{l}\text { The project for the development } \\
\text { of doctoral research is the (co) } \\
\text { authorship of the supervisor. }\end{array}$ & 29.5 & 42.9 & 14.3 & 12.5 & 2.88 & 0.60 \\
\hline & & & & & Average & 3.13 & 0.77 \\
\hline \multirow{4}{*}{$\begin{array}{l}\text { Supervision } \\
\text { competence }\end{array}$} & $\begin{array}{l}\text { Knowing how to teach is } \\
\text { essential in supervision }\end{array}$ & 42.9 & 44.6 & 7.1 & 4.5 & 3.24 & 0.84 \\
\hline & $\begin{array}{l}\text { Supervision is the most } \\
\text { demanding task of university } \\
\text { teaching processes. }\end{array}$ & 23.2 & 40.2 & 21.4 & 15.2 & 2.71 & 0.48 \\
\hline & $\begin{array}{l}\text { The creativity and innovation of } \\
\text { the supervisor are very important } \\
\text { in solving problems that arise } \\
\text { during doctoral research. }\end{array}$ & 56.3 & 34.8 & 6.3 & 0.9 & 3.43 & 1.04 \\
\hline & & & & & Average & 3.13 & 0.79 \\
\hline \multirow{7}{*}{ PhD outcomes } & $\begin{array}{l}\text { The writing of scientific articles } \\
\text { is one of the learning outcomes } \\
\text { that should occur during the } \\
\text { doctorate. }\end{array}$ & 81.3 & 15.2 & 1.8 & 1.8 & 3.76 & 1.55 \\
\hline & $\begin{array}{l}\text { Most important in the doctorate } \\
\text { is the knowledge that is built. }\end{array}$ & 28.6 & 60.7 & 9.8 & 0.9 & 3.17 & 0.85 \\
\hline & $\begin{array}{l}\text { To complete a doctorate, a } \\
\text { student must know how to } \\
\text { communicate his research. }\end{array}$ & 92.9 & 6.3 & 0.0 & 0.0 & 3.90 & 1.83 \\
\hline & $\begin{array}{l}\text { The development of research } \\
\text { skills is the main objective of } \\
\text { pursuing a PhD }\end{array}$ & 41.1 & 50.9 & 6.3 & 0.9 & 3.30 & 0.88 \\
\hline & $\begin{array}{l}\text { Resilience is one of the } \\
\text { competence to be developed by a } \\
\text { doctoral student during his PhD. }\end{array}$ & 69.6 & 23.2 & 5.4 & 0.9 & 3.60 & 1.29 \\
\hline & & & & & Average & 3.55 & 1.28 \\
\hline & & & & & $\begin{array}{c}\text { Total } \\
\text { average }\end{array}$ & 3.32 & 1.01 \\
\hline
\end{tabular}

The authorship of the thesis is controversial; some supervisors consider themselves co-authors, only half of the responding supervisors consider that the students are the authors of the PhD thesis. This topic is closely related to the integration of the doctoral project into the supervisor's research (which happens in many situations) or to project orientation taking place on a subject that the supervisor masters but is not part of his project. In the first case, the co-authorship is undisputed, while in the second (when the supervisor guides the student in the process) the authorship should be attributed to the student.

One of the statement proposed to the supervisors was "Supervision is the most demanding task of teaching processes in universities." This item assumes that $\mathrm{PhD}$ is the highest academic degree that can be acquired (in Portuguese universities) and as so, will also have the highest standards of teaching and learning, but this assumption does not match the perceptions of these supervisors. So for these supervisors "What is the essence of supervising a doctorate? Is the attribute "knowing how to teach" essential to supervise (guide) a student? From the supervisors' responses, it can be seen that only $44.9 \%$ agree that "Knowing how to teach is essential for supervising" and $44.6 \%$ partially agree. It should be noted that this data is reinforced by the responses regarding the statement "Orientation is the most demanding task of 
teaching processes at universities" located between the options partially agree and partially disagree (2.71).

In 2013 Bruce and Stoodley presented the results of an investigation they conducted with supervisors about experiencing supervision as teaching at an Australian University. These authors point out that "Supervision as teaching was experienced as promoting the supervisor's development, imparting academic expertise, upholding academics standards, promoting learning to research, drawing upon student expertise, enabling student development, venturing into unexplored territory, forming productive communities and contributing to society."(Bruce \& Stoodley, 2013: 226). In the present study, it is clear that supervision is not perceived by all supervisors as a teaching process: only $44.9 \%$ of supervisors agree that knowing how to teach is essential for supervision. On the one hand, because the teaching process has different characteristics of graduate education and the transmission of knowledge is different, on the other, because the background of supervisors (Portuguese and Australian) in terms of Supervisory training is different. In Australia, supervisors have to have supervisory training to do so. In Portugal, by the law, it is only necessary to have a $\mathrm{PhD}$.

The knowledge that is built is also not considered the most important in the doctorate for supervisors; only $28.6 \%$ agree with the statement "The most important thing in the doctorate is the knowledge that is built" and $60.7 \%$ partially agree.

The statement that generates the most consensus is that "The creativity and innovation of the supervisor are very important in solving problems that arise during doctoral research." $56.3 \%$ of supervisors agree with it and $34.8 \%$ partially agree. But, if on one hand it shows the importance given by the supervisors to their creativity and innovation, on the other hand, it arises questions: "how do they develop students' creativity and innovation during the $\mathrm{PhD}$ ? This theme will be explored in future research.

\subsection{Supervision Practices in the Supervisor Lens}

Practically all supervisors ask the doctoral students to read the papers $(98 \%)$, present the results in congresses $(94 \%)$, write at least one article during the doctorate $(92 \%)$, participate as speakers in workshops $(88 \%)$, discuss ideas with peers $(86 \%)$, monitor their research $(85 \%)$, give suggestions regarding their doctoral research $(83 \%)$ and attend meetings of the research group (82\%). Half of the supervisor's request that doctoral students have written records of their activities and $47 \%$ demand students to submit an annual report.

Writing papers is not only a form of doctoral pedagogy (Kamler \& Thompson, 2004; Lassig, Lincoln, Dillon, Diezmann, Fox \& Neofa, 2009) but also an activity that facilitates the integration of the doctoral student into the academic field and into a scientific career, being one of the quality descriptors of doctoral education and research (LERU, 2007). Horta and Santos (2016) reported that the impact of publications during doctorate on the career of doctorates (number of publications, visibility and collaborations) in Portugal, is very important- $\mathrm{PhD}$ with the highest number of publications during their doctorate, have more citations and citations in the future in their research career than doctoral students who did not publish during the doctorate. They realise that those who publish during the $\mathrm{PhD}$, publish more articles as sole author, and engage in peer-to-peer publications from other institutions, suggest greater levels of international autonomy and dynamics of collaboration (Horta \& Santos, 2016). In this context, the fact is that $92 \%$ of supervisors state that they request the writing of papers may be an indication that they are promoting dynamics of integration in the academic environment and the autonomy of doctoral students. This is a theme that will be deepening the next research.

\subsection{The Interpersonal Relation between Supervisor and Doctoral Student}

The relationship established between the supervisor and the doctoral student must be more professional rather than personal, and the supervisory process must be transparent. At UNL the "supervision rules" (meaning rules as rights and duties of each of the stakeholders involved in the supervision process) are not always explicit when the acceptance of the supervisory process occurs, but $35.7 \%$ of supervisors refer that they do it. This "work contract" will enable the doctoral student and the supervisor to know how to act in situations that may arise during the supervisory process. Note that the fifth principle of Salzburg (2005) states that "in respect of individual doctoral candidates, arrangements for supervision and assessment should be based on a transparent contractual framework of shared responsibilities among doctoral candidates, supervisors and the institution (...)", which gives importance to the recognition of the relevance of clarifying the supervision and evaluation rules, as shown in table 6.

Regarding the statement "For the completion of the doctorate there must be a good supervisor-student relationship", the percentage of supervisors who agree with it is $52.7 \%$ and $40.2 \%$ partially agree with the same. Hierarchy, as well as the type of leadership, is important in framing the doctoral supervision process because, without them, the role of the supervisor is not understood. During the doctoral investigation process, the supervisor is someone who, not only guides but advises the student, from a higher position. The latter should provide appropriate information for solving the problems of the research process and should promote decision making and above all promote the development of student autonomy based on informed choices. However, only $22.3 \%$ of 
supervisors agree that it is important to establish a $\mathrm{PhD}$ student-supervisor hierarchy, and $17.9 \%$ of supervisors disagree with it.

Bearing in mind that the doctoral student is a future researcher and that the doctoral supervisor plays an essential role in his / her integration into the research environment (academic or not), the supervisor has the responsibility for the research training of the doctoral student and his integration into a research team, but also the responsibility to prepare the doctoral student for a future career. In this sense, it is important to understand if the supervisor feels responsible for the success or failure of his doctoral students. In this context, statements that implicitly inform about the perceptions of supervisors regarding the career of the doctoral student were presented. Regarding the sentence "The successful completion and completion of the doctoral research project are only the student's responsibility", the disagreement was $36.6 \%$, and $33 \%$ partially disagree, reflecting the degree of responsibility felt by supervisors regarding the non-completion of the doctorate.

Table 6. Degree of agreement regarding statements about the supervisor-student relationship.

\begin{tabular}{|c|c|c|c|c|c|c|c|}
\hline \multirow{2}{*}{$\begin{array}{l}\text { Interpersonal } \\
\text { relationship }\end{array}$} & \multirow{2}{*}{ Statement } & \multicolumn{4}{|c|}{$\begin{array}{c}\text { Percentage of respondents by degree of } \\
\text { agreement }\end{array}$} & \multirow{2}{*}{ Average } & \multirow{2}{*}{$\begin{array}{l}\text { Standard } \\
\text { deviation }\end{array}$} \\
\hline & & Agree & $\begin{array}{c}\text { Partially } \\
\text { agree }\end{array}$ & $\begin{array}{l}\text { Partially } \\
\text { Disagree }\end{array}$ & Disagree & & \\
\hline \multirow{3}{*}{$\begin{array}{l}\text { Student-supervisor } \\
\text { relationship }\end{array}$} & $\begin{array}{l}\text { For the completion of the } \\
\text { doctorate there must be a good } \\
\text { supervisor - student relationship. }\end{array}$ & 52.7 & 40.2 & 4.5 & 2.7 & 3.43 & 0.99 \\
\hline & $\begin{array}{l}\text { Establishing a hierarchy between } \\
\text { supervisor and doctoral student is } \\
\text { important. }\end{array}$ & 22.3 & 37.5 & 21.4 & 17.9 & 2.63 & 0.43 \\
\hline & & & & & Average & 3.03 & 0.71 \\
\hline \multirow[t]{3}{*}{ Project rules } & $\begin{array}{l}\text { The formalization of the } \\
\text { guidelines (tasks to be performed } \\
\text { by the student) of the supervisor is } \\
\text { fundamental for the completion of } \\
\text { the doctorate }\end{array}$ & 31.3 & 45.5 & 19.6 & 2.7 & 3.04 & 0.65 \\
\hline & $\begin{array}{l}\text { Doctoral students must strictly } \\
\text { comply with the work plan } \\
\text { outlined by me. }\end{array}$ & 3.6 & 28.6 & 40.2 & 25.9 & 2.06 & 0.37 \\
\hline & & & & & Average & 2.55 & 0.51 \\
\hline \multirow{5}{*}{$\begin{array}{l}\text { PhD Student } \\
\text { Career }\end{array}$} & $\begin{array}{l}\text { Successful implementation and } \\
\text { completion of the doctoral } \\
\text { research project is the sole } \\
\text { responsibility of the student. }\end{array}$ & 2.7 & 27.7 & 33.0 & 36.6 & 1.96 & 0.32 \\
\hline & $\begin{array}{l}\text { A doctoral student is a future } \\
\text { higher education researcher / } \\
\text { teacher. }\end{array}$ & 13.4 & 39.3 & 18.8 & 26.8 & 2.36 & 0.41 \\
\hline & $\begin{array}{l}\text { A PhD student is someone who } \\
\text { wants a solid higher education but } \\
\text { does not want an academic career. }\end{array}$ & 6.3 & 43.8 & 37.5 & 9.8 & 2.41 & 0.55 \\
\hline & & & & & Average & 2.24 & 0.43 \\
\hline & & & & & $\begin{array}{c}\text { Total } \\
\text { average }\end{array}$ & 2.55 & 0.53 \\
\hline
\end{tabular}


To better understand how supervisors perceive a doctoral student's future career, the following statements were made: "A doctoral student is someone who wants a solid higher education, but does not want an academic career" and "A doctoral student is a future higher education researcher/teacher". It is interesting to note that if on the one hand, supervisors do not see the doctoral students as a future higher education researcher/teacher (only $13.4 \%$ agreed with the first statement and $26.8 \%$ disagreed), they also do not perceive them as "a person who wants a solid higher education but does not want an academic career" (only 6.3\% agreed with this statement and only $9.8 \%$ disagreed). If for some supervisors $\mathrm{PhD}$ student will be a future researcher or higher education teacher, for others, it will be someone who wants to improve his/her education. The questions that arise are: "What are the implications of these different perceptions in supervisory practices?", "What are the goals and the pathway to achieving a PhD?" and "What to teach?", that is "Which curriculum should be developed?".

\subsection{The Academic Integration}

The present research intends to capture the context and the environment in which the third cycle works in this University. It is intended to do the first approach to the socialization process of $\mathrm{PhD}$ students and the role of their supervisors in their academic development (what strategies, methodologies and practices they use) and in their socialization process.

The theory proposed by Tinto (1993) to explain student retention proposes, according to Pearson is "that student persistence is related to the degree of integration they experience within an institution, having an insufficient personal interaction with others within the institution results in a lack of integration" (Pearson, 2012: 191). Socialization is a determining factor in the success or retention of doctoral students (Gardner, 2008; Gardner, 2010; Pearson, 2012; Kiley, 2015). For Gardner (2009) during the development of the doctoral degree, there are three phases: "Entry" (which corresponds to the arrival at the institution and the establishment of relationships with colleagues and employees of the Institution), "Integration" (which is the time when the student does his doctoral research, consolidates the rules in the place where he works and strengthens personal relationships with the remaining members of the institution) and "Candidacy" (related to the writing and systematization of the knowledge generated, the interpretation of results and the writing of the thesis). These phases are very important for the integration and socialization of the student during the $\mathrm{PhD}$. In the words of Gardner (2008: 126) "Socialization is the process through which an individual learns to adopt the values, skills, attitudes, norms, and knowledge needed for membership in a given, group, or organization". This author advocates that "lack of "fitting the mould"" is one of the factors that lead to the abandonment of doctoral programs, and that socialization, in this case, is transmitted through a culture of higher education. Organizational culture, as Tierney (1997) says, cited by Gardner, is "the sum of activities-symbolic and instrumental- that exists in the organization and creates shared meaning. (...) An organization's culture, then, teaches people how to behave, what to hope for, and what it means to succeed or fail." (Gardner, 2008: 127). In this context, the socialization of doctoral students must take place, so that they acquire a sense of belonging and can integrate themselves in the institution, to be able to finish their doctoral project and conclude the academic degree. According to Weidman, Twale and Stein (2001) socialization occur in four phases - anticipatory, formal, informal and personal - which include the acquisition of knowledge, student engagement in academy activities and the increase of their responsibilities in their area of knowledge. In each phase student involvement with the academy increases.

As academic integration is very important for a good $\mathrm{PhD}$ performance, we tried to perceive if it is done, and in what way. The construction of the statements was based on a model of integration where the supervisor is the mediator between the academy/research group/ host institution and the doctoral student. Looking at our data (Table 7) and relative to the sentence "The supervisor should encourage the participation of $\mathrm{PhD}$ students in working meetings of the research group where they are inserted" almost all the supervisors agree with it. However, this agreement is not corroborated by the option on the following statement "The presentation of the doctoral student to the elements of the research group in which he will be inserted is essential for a good integration in the institution" which may indicate that although there is agreement with the $\mathrm{PhD}$ student participation in the institution activities, it may not be felt by the student if the doctoral student is not presented to the research group. This situation may lead to student isolation (which is in agreement with the fact that most supervisors consider that pursuing a $\mathrm{PhD}$ is a lonely process). 
Table 7. Degree of agreement on integration in university

\begin{tabular}{|c|c|c|c|c|c|c|c|}
\hline \multirow{2}{*}{$\begin{array}{l}\text { Integration in } \\
\text { Academia }\end{array}$} & \multirow{2}{*}{ Statement } & \multicolumn{4}{|c|}{$\begin{array}{c}\text { Percentage of respondents by degree of } \\
\text { agreement }\end{array}$} & \multirow{2}{*}{ Average } & \multirow{2}{*}{$\begin{array}{l}\text { Standard } \\
\text { deviation }\end{array}$} \\
\hline & & Agree & $\begin{array}{c}\text { Partially } \\
\text { agree }\end{array}$ & $\begin{array}{l}\text { Partially } \\
\text { Disagree }\end{array}$ & Disagree & & \\
\hline \multirow{3}{*}{ Socialization } & $\begin{array}{l}\text { The supervisor should encourage the } \\
\text { participation of doctoral students in } \\
\text { working meetings of the research group } \\
\text { where he / she is inserted during the } \\
\text { doctorate. }\end{array}$ & 87.5 & 9.8 & 0.9 & 0.0 & 3.81 & 1.70 \\
\hline & Doing a doctorate is a solitary process. & 9.8 & 33.9 & 18.8 & 37.5 & 2.16 & 0.32 \\
\hline & $\begin{array}{l}\text { The presentation of the doctoral student } \\
\text { to the elements of the research group in } \\
\text { which he will be inserted is essential for } \\
\text { a good integration in the institution. }\end{array}$ & 68.8 & 25.9 & 2.7 & 0.0 & 3.58 & 1.29 \\
\hline \multirow{6}{*}{$\begin{array}{l}\text { Tasks in the host } \\
\text { institution }\end{array}$} & & & & & Average & 3.18 & 1.10 \\
\hline & $\begin{array}{l}\text { During the doctorate, the doctoral } \\
\text { student should streamline activities in } \\
\text { the host institution: teaching, presenting } \\
\text { his research work in departmental } \\
\text { seminars. }\end{array}$ & 36.6 & 43.8 & 11.6 & 5.4 & 3.06 & 0.73 \\
\hline & $\begin{array}{l}\text { During the doctorate, the doctoral } \\
\text { student must enrol in activities at the } \\
\text { host institution, such as: organizing } \\
\text { workshops, organizing debate sessions } \\
\text { and discussion of topics relevant to the } \\
\text { institution }\end{array}$ & 29.5 & 44.6 & 14.3 & 9.8 & 2.90 & 0.62 \\
\hline & $\begin{array}{l}\text { Doctoral students should teach at least } \\
\text { once while doing their doctorate. }\end{array}$ & 21.4 & 39.3 & 19.6 & 17.9 & 2.61 & 0.45 \\
\hline & & & & & Average & 2.86 & 0.60 \\
\hline & & & & & $\begin{array}{c}\text { Total } \\
\text { average }\end{array}$ & 3.02 & 0.85 \\
\hline
\end{tabular}

The presentation of the doctoral students to the research team does not lead to the agreement of all supervisors, only $68.8 \%$ agree with it. Only $37.5 \%$ of the supervisors disagree with the statement "Doctorate is a solitary process". This statement is different from the statement "Doing a $\mathrm{PhD}$ is an individual process." (Not on the questionnaire), while the former refers to the loneliness and isolation of the process, the second (not on the questionnaire) refers to the unique and personal character of each doctoral project. The statement "Doctorate is a solitary process" was chosen due to the importance that loneliness and isolation have on student giving up the $\mathrm{PhD}$ project. The fact that the student feels isolated and apart from or away from the academy does not promote a sense of belonging (Gardner, 2009). Looking data some questions arise: "If the presentation of the doctoral student to the members of the research group to which he will be inserted is not essential for good integration in the institution, what will be essential? How do these supervisors propose to integrate the student into the academy? Without integration into the research group and the institution's culture, it is unlikely that the student will be integrated into the academy, which may lead to their isolation.
Another issue that has emerged from this research work is the question "How teamwork during the doctoral project can favourably interfere with $\mathrm{PhD}$ integration, but detract from the student's ability to develop creativity and originality in their work?". If, on the one hand, the fact that the student is isolated and not working in a team (although theoretically integrated into a research team) does not allow him to develop decision-making skills in complex situations, interact with different people, coordinate or be coordinated in work teams, and develop leadership competencies and their skills as a researcher in a research team. On the other, being integrated into the research group will allow them to participate in the development of a project or common good to all elements of the research team, but, their originality, creativity and autonomy can be sacrificed to achieve the team's goal. Although the doctoral project should be an innovative and original contribution, it should not imply student isolation. Regarding the creation/conception project, the fact that supervisors agree $(41.1 \%)$ or partially agree $(42.9 \%)$ that "A PhD student's research project should articulate with the supervisor's research interests" implies that it should benefit the supervisors' research, and they should be integrated into their project. It should be emphasized that 
if supervisors consider that the student's research project should articulate with their research interests, then, implicitly, the doctoral research project should in some way "help" the project of the supervisor and thus contribute to the development of research group projects where the doctoral students should be inserted and integrated. It is important to focus that the $\mathrm{PhD}$ student is not an executor of the supervisor's research, but, can create knowledge that can complete or give another perspective to supervisor research. So it makes sense to include the PhD student in the research team.

As for the statement "During the $\mathrm{PhD}$, the student should have activities at the host institution: teaching, presenting their research work in department seminars", $36.6 \%$ of the supervisors show agreement and $43.8 \%$ of supervisors partially agree with it. Concerning the promotion of activities by $\mathrm{PhD}$ students ("During the doctorate, the doctoral student should participate in activities in the host institution, such as organizing workshops, organizing discussion sessions and discussion of topics relevant to the institution") $9.8 \%$ of supervisors disagree with it and $14.3 \%$ partially disagree. In this situation, the student has an active attitude (organizes). The percentage of disagreement $(17.9 \%)$ with the statement "Doctoral students should teach at least once while doing the doctorate" is similar to the partial disagreement $(19.6 \%)$. This result may be explained by the fact that for some supervisors' lens, doctoral students should be dedicated to research exclusively.

With these results, it is possible to verify that the degree of disagreement increases with the students' involvement in the institution activities and the degree of agreement decreases. These results may indicate that the integration of the doctoral student in the institution's activities which are not directly related to the doctoral journey research project is not perceived by the supervisor as positive. This result should be interpreted in the light of the meaning that the supervisor has the doctorate; during the doctorate the doctoral research project should occupy a student full-time. This position may also be related to the fact that currently, the time of completion of doctorates (time defined by educational institutions) is limited and may influence the evaluation of the supervisor and indirectly their career.

\subsection{Supervisors Difficulties}

To understand the difficulties experienced by $\mathrm{PhD}$ supervisors, supervisors were asked, "What difficulties do supervisors come across daily?" From the analysis of the results, it appears that the greatest difficulties felt by the supervisors related to the doctoral students focus and motivation $(46 \%)$, the doctoral student personal profile (27\%) and the management of conflicts and expectations $(15 \%)$. Regarding the difficulties at an institutional level, the lack of time (reported by $27 \%$ of supervisors), as well as the lack of funding (referred by $25 \%$ of supervisors), can be highlighted. Noteworthy here is the inconsistency between the lack of time reported here by $27 \%$ of supervisors and the disagreement of $34.8 \%$ (and partial disagreement of $26.8 \%$ ) of supervisors with the statement "I have a lot of work and less time to do doctoral supervision."

Some of these difficulties may be overcome if the institutions provide training in this regard. The difficulties experienced by supervisors may be an obstacle to supervisors' acceptance of supervision and should be taken into account by the institutions to improve the welfare of supervisors. It should also be noted that some of the quality descriptors proposed for doctoral supervision of the Association of European Institutions and Colleges of Biomedicine and Health Sciences (ORPHEUS, 2011 and 2012), meet the results found. These descriptors indicate that to be a supervisor, one must have: a formal qualification (usually a doctorate or experience at that level), experience in a specific area (must be active at the research level), affiliated at an eligible institution, and funding for research projects. Observing the results, it is possible to perceive that these last two conditions do not always exist.

A longitudinal study conducted in 2016 at the University of Auckland in New Zealand showed that supervisory difficulties at this institution focus on three areas: communication, project management and thesis writing (Carter, Kensington-Miller \& Courtney, 2017). Considering our results, it is possible to verify that the supervision problems found at UNL essentially were related to two areas: the supervisor-student relationship (which includes student characteristics, conflict management and expectations, motivation, and student time management) and supervision within the institution's organization. These difficulties were also felt by supervisors of Australian Universities in the early 21st century who, to support supervisors, provided training in areas such as supervisor/student relations, supervisors and doctoral expectations, research progress monitoring and institutional policies (Kiley, 2011).

The motivation given to the student by the supervisor extrinsic motivation - is essential when the student is experiencing difficulties. The following statement was placed on the questionnaire to perceive the degree of extrinsic motivation given by supervisors: "The ability to motivate is very important in a counsellor", $84.8 \%$ of supervisors agreed with the statement, $14.3 \%$ supervisors partially agreed and no supervisor disagreed or partially disagreed. These results highlight the importance given by supervisors to student motivation and give internal consistency to this research as they corroborate the results reported in the previous section (student motivation during $\mathrm{PhD}$ is one of the difficulties experienced by $46 \%$ of responding supervisors). 


\section{Conclusions}

The effect that this research had on the institution, in the first place was triggering a comprehensive reflection on the topic of doctoral supervision, in which supervisors were invited to participate, within the higher education institution, and showed that doctoral supervision is no longer a private place. Doctoral supervision must be discussed and supervisors should be prepared for it. It is important to emphasize that it's a demanding teaching process, that should be scrutinized, monitored and assessed not only by peers and the host institution but also by the PhD students.

Based on collecting data, it is possible to perceive that regarding research competencies, if on one hand, most supervisors consider that there are students who do not have them or don't develop them during the PhD research, which undermines the degree conclusion. On the other, to choose doctoral students to supervise, supervisors take into account the student's motivation, personality, area of interest, their curriculum but also cognitive factors (evidenced skills and abilities). Surprisingly, although supervisors' refer that some students' don't have the skills to complete the degree, only a few supervisors consider the students' competencies and skills at the time of choosing students to supervise. It is necessary, and imperious to perceive why there are students that don't develop research competence during the $\mathrm{PhD}$ research.

To the supervisors, the primary function of the supervisor is not to show to research tools, but to develop a student's autonomy and research skills. The supervisor must not only accompany the project but, also promote its conclusion. In this sense, planning is usually carried out jointly by the doctoral student being responsible for both.

For supervisors, the writing process of the thesis is not the most difficult task developed by a $\mathrm{PhD}$ student during $\mathrm{PhD}$ research nor do they consider that they have insufficient time to do supervision - only $9.8 \%$ of supervisors agree with the sentence "I have a lot of work and insufficient time to do supervision". The hardest assignment is student engagement and focuses on the research project. This is a supervisor challenge since the student engagement is not always satisfactory from the supervisor lens.

Some supervisors present supervisory rules at the beginning (professional attitude recommended by international reports), to clarify the roles that stakeholders will play. This will make it easier to deal with "conflict" situations, frame behaviours and manage expectations of both the supervisor and the doctoral student.

The most requested activities, proposed by supervisors to $\mathrm{PhD}$ students, are reading articles, presenting results in congresses, writing articles, participating as speakers in workshops, seminars and congresses, exchanging ideas among doctoral student peers and regularly reviewing the research.
Concerning the monitoring of project development, there is a consensus regarding the need for regular contact with the student, which may be in person or not, individually or in groups. But writing is not a strategy that supervisors use to promote student monitoring and self-regulation. To evaluate the work done by the doctoral student, few supervisors consider relevant the submission of written documents (reports, monographs, papers, abstracts). It is important to note that the type of feedback given by supervisors is rarely written, but is predominantly oral, which may result in a loss of quality and information. Supervisors do not promote the student record writing at these meetings, so the information transmitted and feedback is not registered.

Thus the general conception of supervision fits into a view related to the nature of the doctoral process: the doctorate is seen as a process, as a product and as a way of choosing and training a research team and having research help. But, $\mathrm{PhD}$ is also perceived as useful (career progression), with the intrinsic importance (motivation and interest) and extrinsic importance (professional duty/ paper production) and is accountable.

One of the most relevant aspects of supervision is related to the process of integration and the socialization that occurs during supervision. Since the supervisor is the interface between the academy and the doctoral student, he should prevent doctoral student isolation. The student needs to know the rules and the culture of the research group in which he is inserted but also needs to share his problems and achievements. The process of supervision as a process of socialization is a process under construction, being the way of integration of the future researcher in the academy.

The quality parameters linked to doctoral supervision (ORPHEUS, PhD Quality Indicators, 2011) state that the responsibility of the supervisor can be assessed by the extent to which the supervisor gives project advice, monitors and documents research progress, has an appropriate ethical and scientific conduct and supports the doctoral student's later career. Supporting the career of doctoral students is not visible from the data collected. Therefore, they do not feel responsible for the professional career of doctoral students, which is one of the attributes of a supervisor (ORPHEUS, 2011 and 2012; LERU, 2007, 2014 and 2016).

The difficulties mentioned by the supervisors were grouped in those experienced by the supervisors taking into account the doctoral student profile and taking into account the supervisory process at the institution. The first one was: the personal characteristics of the students; the conflict management and expectations; student motivation, focus and time management. Given the difficulties experienced by supervisors regarding the supervisory process at the institution, the areas identified were: the supervisors' lack of time; time management; the alignment between the research interests of the supervisor and the 
doctoral student; financing and others.

It was not possible to identify instruments used for monitoring or evaluation of supervision. The document entitled Standards and guidelines for quality assurance in the European area of higher education (2015) highlights not only guidelines for ensuring the internal quality of higher education, but also proposals for ensuring external quality. It should also be based on self-assessment and peer review and that the criteria used in it should be clear, explicit and public. Self-assessment implicitly relies on monitoring as well as evaluation, taking into account the objectives and what has been achieved with the strategies used.

Monitor supervision is experienced differently by supervisors as is supervision assessment. Regular meetings with other fellow supervisors are only held by $43.8 \%$, while a minority $(10.7 \%)$ does not hold them. The majority of the supervisors consider that sharing information is useful and that they should be monitored. This may be a clue to the existence of "communities of practice" among $\mathrm{PhD}$ supervisors, which supports them.

Regarding the quality assurance of supervision, only a minority of supervisors $(19.6 \%)$ believe that external monitoring favours doctoral supervisors. Although these results do not make clear that supervisors carry out project monitoring, there are indications that it is done informally, through regular meetings with the doctoral students. Regarding supervisory assessment, some supervisors $(12.5 \%)$ consider it unnecessary, but $33 \%$ consider it necessary. Without supervisory monitoring and evaluation, how do supervisors realize if effectively, they achieve the supervision goals? Promoting quality-standards based supervision, first implies recognizing that there are quality benchmarks, and then realizes the extent to which they have been achieved.

\section{Limitations}

The limited numbers of supervisors that participate in this study don't permit to generalize the results to all UNL schools or characterize the UNL supervisors or even the $\mathrm{PhD}$ supervision process. The results only allow a reflection about the doctoral supervision process based on a small population of supervisors from UNL. Nevertheless, this study endorsed a first glimpse of what the feelings of the supervisors are regarding doctoral education and allowed the emergence of questions during the research, which will be addressed in future research.

\section{REFERENCES}

[1] Abdullah, M. \& Evans, T. (2012). The relationships between postgraduate research students "psychological attributes and their supervisors ${ }^{e e}$ supervision training. Procedia Social and Behavioral Sciences, 31, 788-793.

[2] Askew, C., Dixon, R., McCormick, R., Callaghan, K., Wang, G., Shulruf, B. (2016). Facilitators and barriers to doctoral supervision: A case study in health science. Issues in Educational Research, 26, 1-9.

[3] Beer, M \& Mason, R. (2009). Using a blended approach to facilitate postgraduate supervision. Innovations in Education and Teaching International, 46, 213-226.

[4] Boehe, Dirk. (2016). Supervisory styles: a contingency framework, Studies in Higher Education, 41:3, 399-414. DOI: $10.1080 / 03075079.2014 .927853$

[5] Bruce, C. \& Stoodly, I. (2013). Experiencing higher degree research supervision as teaching. Studies in Higher Education, 38, 226-241.

[6] Carter, S., Kensigton-Miller, B. \& Courtney, M. (2017). Doctoral Supervision Practice: What's the problem and how can we help academics? Journal of Perspectives in Applied Academic Practice, 5, 13-22.

[7] Duke, D. \& Denicolo, P. (2017). What supervisors and universities can do to enhance doctoral student experience (and how they can help themselves). FEMS Microbiology Letters, 364, fnx090.

[8] Franke, A \& Arvidsson, B. (2011). Research supervisors' different ways of experiencing supervision of doctoral students, Studies in Higher Education, 36, 7-19.

[9] Gardner, S. (2007). I heard it through the grapevine. Doctoral student socialization in chemistry and history. Higher Education, 54, 723-740.

[10] Gardner, S. (2008). Fitting the model of graduated school: a quantitative study of socialization in doctorate education. Innovations in Higher Education, 33, 125-138.

[11] Gardner, S. (2009). Student and faculty attributions of attrition in high and low-completing doctoral programs in the United States. High Education, 58, 97-112.

[12] Gardner, S. (2010). Faculty perspectives on doctoral student socialization in five disciplines. International Journal of doctoral Studies, 5, 39-53.

[13] Gatfield, T. (2005). An Investigation into PhD supervisory management styles: development of a dynamic conceptual model and its managerial implications. Journal of Higher Education Policy and Management, 27, 311-325.

[14] Horta, H. \& Santos, J. (2016). The impact of publishing during $\mathrm{PhD}$ studies on career research Publication, Visibility, and Collaborations. Res. High Educ., 57, 28-50. DOI 10.1007/s11162-015-9380-0

[15] Ismail, A., Abiddin, N., Hassan, R \& Ro“is, I. (2014). The profound of students'supervision practice in higher education to enhance student development. Higher Education Studies, 4, 1-6.

[16] Johnston, L., Sampson, K., Corner, K. \& Brogt, F. (2016). Using doctoral experience survey data to support developments in postgraduate supervision and support. International journal of Doctoral Studies, 11, 185-203.

[17] Jones, M. (2013). Issues in Doctoral Studies - Forty Years of 
Journal Discussion: Where have we been and where are we going? International Journal of Doctoral Studies, 8, 83-104.

[18] Kamler, B. (2008). Rethinking doctoral publication practices: writing from and beyond the thesis. Studies in Higher Education, 33, 283-294.

[19] Karmler, B \& Thompson, P. (2004). Driven to abstraction: doctoral supervision and writing pedagogies. Teaching in Higher Education, 9, 195-209.

[20] Kiley, M. (2011). Developments in research supervisor training: causes and responses. Studies in Higher Education, 36, 585-599.

[21] Kiley, M. (2015). I didn't have a clue what they were talking about": $\mathrm{PhD}$ candidates and theory. Innovations in Education and Teaching International, 52, 52-63.

[22] Lassig, C., Lincoln, M., Dillon, L., Diezmann, C., Fox, J. \& Neofa, Z. (2009). Writing together, learning together: the value and effectiveness of a research writing group for doctoral students. Australian Association for research in Education 2009, International Education Research Conference, 29 Novembre-3 December 2009, Canberra.

[23] Lee, A. (2007). Developing effective supervisors: Concepts of research supervision. South African Journal of Higher Education, 21, 680-693.

[24] Leep, L., Remmik, M., Karm, M. \& Leijen, A. (2013). Supervisors' conceptions of doctoral studies. TRAMES, 17, 401-415.

[25] LERU (2014). Good Practice Elements in Doctoral Training. Retrieved in 2 of July 2018 fromhttps://www.leru.org/publications/good-practice-elem ents-in-doctoral-training

[26] LERU (2016). Maintaining a quality culture in doctoral education: At research-intensive universities. Retrieved in 2 of July 2018 from https://www.leru.org/publications/maint aining-a-quality-culture-in-doctoral-education-at-research-i ntensive-universities.

[27] LERU (League of research Universities) (2007). Doctoral studies in Europe: Excellence in researcher training. Retrieved in 2 of July 2018 from https://www.leru.org/files /Doctoral-Studies-in-Europe-Excellence-in-Researcher-Tra ining-Full-paper.pdf.

[28] Maxwell, T. \& Smyth, R. (2010). Research supervision: The research management matrix. Higher Education, 59, 407-422.

[29] Maxwell, T. \& Smyth, R. (2011). Higher degree research supervision: From practice toward theory. Higher Education Research \& Development, 30, 219-231

[30] Mosher, R. \& Purpel, D. (1972). Supervision: The reluctant Profession. Boston. Massachusetts. Houghton Mifllin.

[31] Orlikowski, W. (2002). Knowing in practice: enacting a collective capability in distributed organizing. Organizing Science, 13, 249-273.

[32] ORPHEUS (2011 e 2012) homepage (www.orpheus-med.org).

[33] Pearson, M. \& Brew, A. (2002). Research training and supervision development. Studies in Higher Education, 27,
$135-150$.

[34] Pearson, M. (2012). Building bridges: higher degree student retention and counseling's support. Journal of Higher Education Policy and Management, 34, 187-199.

[35] Pearson, M., Evans, T. \& Macauley, P. (2012) Exploring the nexus between research and doctoral education. AARE APERA International conferece, Sydney, 1-9.

[36] Petersen, E. B. 2007. Negotiating academicity: Postgraduate research supervision as category boundary work. Studies in Higher Education 32(4): 475-487.

[37] Repečkaitè, D. (2016). Reframing European doctoral training for the new ERA. European Journal of Higher Education, 6, 256-270.

[38] Ribau, I. \& Alves, M. (2017). Doctoral supervision at Nova Lisbon University: an exploratory study. European Proceedings of Social and Behavioural Sciences. Paper presented at 8th ICEEPSY, 11- 14 October Porto, Portugal.

[39] Ribau, I. \& Alves, M. (2018). Doctoral supervision at NOVA Lisbon University: an overview. Universal Journal of Educational Research, 6, 2530 - 2542.

[40] Ribau, I. (2018). PhD Supervision: An Exploratory and a Preliminary Study about the Supervisor Point of View. PEOPLE: International Journal of Social Sciences, 4(2), 820-836. https://dx.doi.org/10.20319/pijss.2018.42.820836.

[41] Sala-Bubaré, A., Peltonen,J., Pyhältö, K. \& Castelló, M. (2018). Doctoral candidates' research writing perceptions: a cross-national study. International Journal of Doctoral Studies, 13, 327-345.

[42] Salzburg Final Report. (2005). Bologna seminar doctoral programmes for the European knowledge society. Retrieved

from www.eua.be/eua/jsp/en/upload/Salzburg_Report_fina 1.1129817011146.pdf (10/2/2016)

[43] Shibayama, Sotaro. (2018). Sustainable development of science and scientists: Academic training in life science labs. Research Policy. 10.1016/j.respol.2018.10.030.

[44] Styles, I., \& Radloff, A. (2001). The Synergistic Thesis: Student and Supervisor Perspectives. Journal of Further and Higher Education, 25, 97-106.

[45] Vilkinas, T. (2008). An exploratory study of the supervision of Ph.D./Research students' theses. Innovative Higher Education (2008) 32, 297-311.

[46] Vilkinas, T., \& Cartan, G. (2006). The integrated competing values framework: Its spatial configuration. Journal of Management Development, 25, 505-521

[47] Weidman, J., Twale, D. \& Stein, E. (2001). Socialization of graduate and professional Students in higher education: A perilous passage? San Francisco, CA: Jossey-Bass.

[48] Wright, A., Murray, J. \& Geale, P. (2007). A phenomenographic study of what it means to supervise doctoral students. Academy of Management Learning \& Education, 8, 458-474. 